\title{
The Analysis of Determining Credit Worthiness Using Weighted Product and SMART Methods in SPB Cooperatives
}

\author{
A I Warnilah *1, I N Hawa ${ }^{2}$, Y S Mulyani ${ }^{3}$ \\ 1,2,3 Department of Information System, Universitas Bina Sarana Informatika
}

E-mail: ai.aiw@bsi.ac.id ${ }^{* 1}$,intanmagdelaine@gmail.com², yani.ymn@bsi.ac.id ${ }^{3}$

Submitted: 22 January 2020, revised: 7 February 2020, accepted: 24 February 2020

\begin{abstract}
Abstrak. Koperasi Simpan Pinjam Simpeunan Pameungkeut Banda adalah koperasi yang didirikan di Tasikmalaya. Sistem penyaluran kredit yang saat ini digunakan di Koperasi Banda Simpeunan Pameungkeut masih manual, sehingga pengelolaannya membutuhkan waktu yang cukup lama. Selain itu, koperasi belum memiliki sistem yang mendukung penentuan keputusan kelayakan kredit. Dengan demikian, kredit tidak tepat sasaran, karena tidak sesuai dengan kriteria yang ditentukan. Untuk alasan ini, penulis membuat penelitian tentang weighted product dan smart methods dalam menentukan kelayakan kredit di Koperasi Banda Pameungkeut. Tujuan penelitian adalah untuk menentukan siapa yang memenuhi syarat dan siapa yang tidak memenuhi syarat untuk mendapatkan kredit. Hasil analisis menggunakan metode weighted product diperoleh nilai tertinggi 0,067 dan nilai terendah 0,032, sedangkan metode SMART memperoleh nilai tertinggi 79,2 dan nilai terendah 25 . Hasil penelitian menunjukkan bahwa metode SMART lebih efektif dalam menentukan kelayakan kredit.
\end{abstract}

Kata kunci: perancangan; pemilihan; peminjaman; Simple Multi Attribute Rating Technique (SMART); Weighted Product; koperasi

\begin{abstract}
The Savings and Loan Cooperative of Simpeunan Pameungkeut Banda is a cooperative that has been established in Tasikmalaya. The system of lending currently used at Simpeunan Pameungkeut Banda Cooperative is still manual, so the management requires quite a long time. Besides that, the cooperative has not had a system that supports in determining the credit worthiness decision. Thus, the credit is not on target, because it does not fit the specified criteria. For this reason, the writers were to make a research on the comparison of weighted product and smart methods in determining credit worthiness in Pameungkeut Banda Cooperative. The purpose of research was to determine who were eligible and who were not eligible to get the credit given the criteria that have been determined using the Weighted Product method and SMART methods. The results of the analysis using the Weighted Product method obtained the highest value of 0.067 and the lowest value of 0.032 , while SMART method obtained the highest value of 79.2 and the lowest value of 25. The results show that SMART method is more effective in determining credit worthiness.
\end{abstract}

Keywords: design; selection; borrowing; Simple Multi Attribute Rating Technique (SMART); Weighted Product; cooperative 


\section{Introduction}

The term of cooperative must be familiar among the people of Indonesia. A Cooperative is a business entity that has a legal entity in Indonesia. Law No. 25 of 1992 explained the meaning of cooperatives as a business entity that consists of people or cooperative legal entities that underlie their activities on cooperative principles as well as a people's economic movement based on the principle of kinship [1].

The Savings and Loan Cooperative of Simpenan Pameungkeut Banda (KSP-SPB) Tasikmalaya located on Jalan R. Ikik Wiradikarta No. 45, Tawangsari Village, Tawang District, Tasikmalaya City, is one of the cooperatives that focuses on the savings and loan sector. The cooperative has been running since 1933, which makes makes the Savings and Loan Cooperative of Simpenan Pameungkeut Banda (KSP-SPB) becomes the oldest cooperative in Tasikmalaya.

According to [2] [3], the principles of granting credit include analysis of 5C Character, Capacity, Capital, Collateral (credit guarantee), Conditions of economics, and 7P is the first step Personality, Party, Purpose, Prospect, Payment, Profitability, and Protection. One of the problems occurring in the Simpeunan Pameungkeut Banda Cooperative is the credit that is not on target and causes loss to the cooperative since the members cannot pay their obligation properly. Therefore, it is very necessary to have a decision support system that can determine the best decisions of prospective borrowers in accordance with predetermined criteria such as deposits, income, character, collateral, conditions of collateral.

\section{Theoretical Framework}

\subsection{Weighted Product Method}

Weighted Product (WP) according to Sianturi Ingot seen in [4] conclude that "Weighted Product (WP) Method is one of the methods used to solve problems. The Weighted Product (WP) method uses Multiplication to link the attribute values (criteria), where the value of each attribute must be raised first with the corresponding attribute weights". Weighted Product (WP) is one of the decision support system methods to help solve the problem of determining the provision of credit with predetermined criteria based on the amount of deposits, income, character, collateral, conditions of collateral [5].

According [4] [5] [6], the steps in the calculation using the Weighted Product method are as :

1. Determine the criteria that will be used as a reference in making decisions

2. Determine the suitability rating of each alternative on each criterion

3. Determine the weight of preference for each criterion

4. Transfer all the attributes for an alternative with the weight as a positive rank for the profit attribute and the negative rank weight for the cost attribute.

5. The multiplication results are summed to produce a value of $\mathrm{V}$ for each alternative

$$
S_{i}=\prod_{j=1}^{n} x_{i j} w^{j}, \mathrm{i}=1,2, \ldots, \mathrm{m}
$$

Where :

$\mathrm{S}:$ Alternative preference is analogous to vector $\mathrm{S}$

$\mathrm{x}$ : Criteria value

$\mathrm{w}:$ Criteria Weights

i : Alternative

j : Criteria

$n$ : Number of criteria

$$
\sum_{j=1}^{n} w_{j}=1
$$


$\mathrm{w}_{\mathrm{j}}$ is a positive value for profit attribute and negative value for cost attribute. The relative preferences of each alternative are given as follows :

$$
V_{i}=\frac{\Pi_{j=1 x_{i j}}^{n} w_{j}}{\Pi_{j=1}^{n}\left(x_{j}\right) w_{j}} ; \mathrm{i}=1,2, \ldots, \mathrm{m}
$$

Where :

$\mathrm{V}$ : Alternative preferences analogous to vector $\mathrm{V}$

$\mathrm{x}$ : Value of the criteria

i : Alternative

\section{A : Criteria}

$\mathrm{n}$ : Number of criteria

* : Number of the criteria that have been assessed in the vector

\subsection{SMART Method}

According to [7], [8], SMART is a method in multi-criteria decision making that was developed by Edward in 1997. This multi-criteria decision making technique is based on the theory that each alternative consists of a number of criteria that have values and each criterion has a weight that describes how important it is compared to other criteria. This weighting is used to assess each alternative in order to obtain the best alternative. SMART uses a linear additive model to predict the value of each alternative. SMART is a flexible decision-making method. SMART is more widely used because of its simplicity in responding to the needs of decision makers and how to analyze responses. The steps to use SMART method are as follows:

1. Determine the number of criteria and sub-criteria (parameters)

2. Determine the weight of each criterion

3. Normalization of criteria weights

Normalization:

4. The information:

$$
\mathrm{Wj}=\frac{X j}{\sum w j}
$$

$\mathrm{Wj}$ : weight of a criterion

$\sum$ wj : total weight of all criteria

Calculating the utility value for each criterion.

The information:

$$
u_{i}\left(\alpha_{i}\right)=100 \frac{\left(C_{\max }-C_{\text {out }}\right)}{\left(C_{\max }-C_{\min }\right)} \%
$$

value of the 1st criteria utility for the i criteria

$C_{\text {max }}$ : maximum criterion value

$C_{\text {min }}$ : minimal criterion value

$C_{\text {out }}$ i: i-th criterion value

5. The information : Calculate the final value of each using the formula from the SMART method

$$
u\left(a_{1}\right)=\sum_{J=1}^{m} w_{j} u_{i}\left(a_{i}\right), \quad \mathrm{i}=1,2, \ldots \mathrm{m}
$$

Where:

$\mathrm{w}_{\mathrm{j}}=$ value of the $\mathrm{jth}$ criteria weighting

$\mathrm{u}_{\mathrm{i}}\left(\mathrm{a}_{\mathrm{i}}\right)=\mathrm{i}$-criterion utility value

Warnilah, Hawa, Mulyani (The Analysis of Determining Credit Worthiness Using Weighted Product and SMART Methods in $S P B$ Cooperatives) 


\section{Methodology}

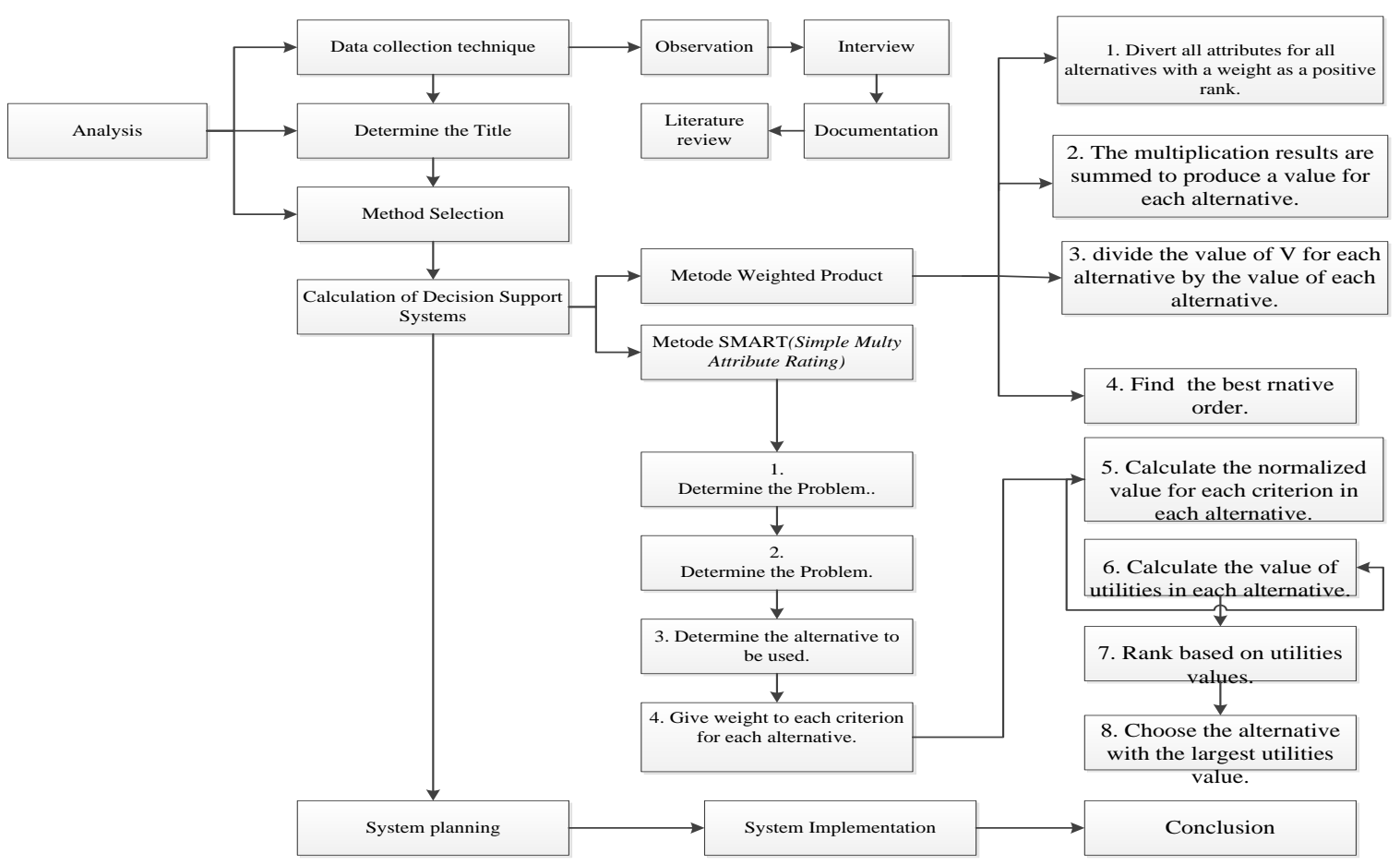

Figure 1. Research Frame

1. Data Collection Techniques

The data were obtained by doing observation, interviews, and literature study. The authors make observations directly to the place of research and conduct interviews. Then, literature study was conducted to gather various information and documents needed in this research. The results obtained using this data collection technique were in the form of a running system in Simepunan Pameungkeut Banda Cooperative, problems to be studied, and important documents needed.

2. Determine the Title

For the first step Had been taken Had been Carried out that has been taken from the results of data collection techniques that have been carried out in Savings and Loan Cooperative of the Pameungkeut Banda Simpeunan with the title Analysis of the Weighted Product Method and SMART (Simple Multy Attribute Rating Technique) in Determining Lending to the SPB Cooperative.

3. Method Selection

for the first step of determining this title, the authors determine the results of research at the research site that had been taken from the results of data collection techniques that had been carried out in Savings and Loan Cooperative of the Simpeunan Pameungkeut Banda.

4. In the Calculation of Decision Support Systems, the authors analyze the data using weighted product method and the SMART (Simple Multy Attribute Rating Technique) method.

5. System Design

The system design is carried out in accordance with the data that has been analyzed.

6. System Implementation

In the implementation of this system, the authors implement the development of a new system from the old system, where problems that occur in the old system are expected to have been resolved in the new system. The authors make the design of a proposed system using the Decision Support System (SPK) Weighted Product Method and the SMART Method (Simple 
Multy Attribute Rating Technique) as a decision maker in granting credit to the Pameungkeut Banda Simpeunan Cooperative.

7. Conclusions

At this step the authors tried to find out which method is more effective in determining the provision of credit to the Simpeunan Pameungkeut Banda Cooperative members.

\section{Results and Discussion}

\subsection{Weighted Product Method}

1. Determine The Criteria

$\mathrm{C} 1=$ Deposit amount is the required deposit amount that must be owned by the borrower using the formula as below:

1) Deposits $2,000,000 \times 4=8,000,000$

2) Deposits $3,500,000 \times 3=10,500,000$

3) Deposits of $5,500,000 \times 2.5=13,750,000$

4) Deposits of $8,000,000$ and above $x 2=$ up to $16,000,000$

This means if the borrower has a saving of 2,000,000, the saving is multiplied by 4 so that the maximum amount that can be borrowed is $8,000,000$. If the borrower has 3,500,000 deposits, it will be multiplied by 3 so that the maximum amount that can be borrowed is $10,500,000$. If the borrower has a savings of $5,500,000$ then it will be multiplied by 2.5 so that the maximum amount that can be borrowed is $13,750,000$. If the borrower has deposits of $8,000,000$ and above, it will be multiplied by 2 so that the maximum amount that can be borrowed is $16,000,000$ or more.

$\mathrm{C} 2$ = Income derived from the work of the borrower

$\mathrm{C} 3$ = Character is an assessment of the borrower's attitude, seen whether previously there was a delinquent payment, or difficulties in paying the bill.

$\mathrm{C} 4=$ Collateral is the assets of the borrower promised to the lender. If the borrower cannot return the loan, the lender can have the collateral.

C5 $=$ Condition is the condition of the proposed guarantee, whether or not it is still feasible to be used as collateral.

2. Determine the compatible rating for each criterion. Match branches are the value of each criterion, each criterion is valued in numbers from 20 to 100. In the table below is a compatibility branch that has values of 20 (very bad), 40 (bad), 60 (sufficient), 80 (good) 100 (very good). The lowest value of the above criteria is 20 and the highest is 100 :

Table 1. Compatible Rating

\begin{tabular}{ll}
\hline \multicolumn{1}{c}{$\begin{array}{c}\text { The level of each } \\
\text { criterion }\end{array}$} & Value \\
\hline Very bad & 20 \\
Bad & 40 \\
Sufficient & 60 \\
Good & 80 \\
Very well & 100 \\
\hline
\end{tabular}

Table 2. Criteria Weight

\begin{tabular}{lll}
\hline Id & Name of criteria & $\begin{array}{c}\text { Value } \\
\text { weights }\end{array}$ \\
\hline C1 & Deposit Amount & 100 \\
C2 & Income & 60 \\
C3 & Character & 60 \\
C4 & Guarantee & 80 \\
C5 & Guarantee & 60 \\
\hline
\end{tabular}

Table 2 explains the names and values or weights in the loan-lending requirements at Pameungkeut Banda Savings and Loan Cooperative. Later, the order in the system of giving credit decisions based on the highest priority is the amount of deposits and subsequently collateral, income, collateral conditions and character.

3. Determine the weighting of each criteria 
After determining the value of the next stage, criteria are made a level of criteria based on alternatives (borrower's criteria) that have been determined into value. The following table represents the faithful compatibility of alternative ratings on each criterion:

a. Criteria For Amount Of Deposit

Criteria for Amount of Deposit In table 3 below explains the assessment of the criteria for the amount of deposits. If the loan amount is 8,000,000 then the minimum amount of deposits owned by the borrower is $2,000,000$. If the loan amount is $10,500,000$ then the minimum amount of deposits owned by the borrower is $13,500,000$. If the loan amount is $16,000,000$ and above then the minimum amount of savings owned by the borrower is $8,000,000$.

Table 3. A Weight of Deposit Amount

\begin{tabular}{cll}
\hline Loan Amount & Minimum of deposit amount & Value \\
\hline & $<=2.000 .000$ & 30 \\
& $=2.000 .000$ & 70 \\
8.000 .000 & $>=2.000 .000$ & 100 \\
& $<=3.500 .000$ & 30 \\
& $=3.500 .000$ & 70 \\
10.500 .000 & $>=3.500 .000$ & 100 \\
& $<=5.500 .000$ & 30 \\
13.750 .000 & $>=5.000 .000$ & 70 \\
& $>=5.000 .000$ & 100 \\
Up to 16.000 .000 & $>=8.000 .000$ & 30 \\
& & 70 \\
& & 100
\end{tabular}

b. Income Criteria

Table 4. The Quality of Income Value

\begin{tabular}{lc}
\hline The Criteria of Borrower & Value \\
& \\
\hline $500.000-1.999 .999$ & 20 \\
$2.000 .000-3.999 .999$ & 40 \\
$4.000 .000-5.999 .999$ & 60 \\
$6.000 .000-9.999 .999$ & 80 \\
$>=10.000 .000$ & 100 \\
\hline
\end{tabular}

In the table above it explains about the value of wages criteria, wages borrower must be minimum up to 500.000 and maximum limit from income is $>=10.000 .000$

c. Character Criteria

Table 5. The Quality of Character Value

\begin{tabular}{lc}
\hline \multicolumn{1}{c}{ The Criteria of borrower } & Value \\
\hline Very bad & 20 \\
Bad & 40 \\
Sufficient & 60 \\
Good & 80 \\
Very good & 100 \\
\hline
\end{tabular}

Warnilah, Hawa, Mulyani (The Analysis of Determining Credit Worthiness Using Weighted Product and SMART Methods in $S P B$ Cooperatives) 
The table explains the assessment of character criteria. The value is based on data from credit lenders. Value of 100 is the highest value of the criteria which is a very good borrower. 80 is good, 60 is good, 40 is less and 20 is very less.

d. Guarantee criteria

The table explains the collateral criteria. These criteria are obtained from the Simpeunan Pameungkeut Banda Cooperative. The Simpeunan Pameungkeut Banda cooperative only accepts BPKB motorbikes, car BPKB guarantees, paddy field and pond certificates, land certificates and house certificates. Minimum year of vehicle warranty is 2008.

Table 6. The Quality of guarantee value

\begin{tabular}{lc}
\hline \multicolumn{1}{c}{ Guaranteed Value Weight } & Value \\
\hline BPKB Motorcycle & 40 \\
BPKB car & 60 \\
Paddy field and pond certificate & 60 \\
Land Certificate & 80 \\
House Certificate & 100 \\
\hline
\end{tabular}

Table 7. The Quality of Guarantee Condition

\begin{tabular}{lc}
\hline \multicolumn{1}{c}{ Match Rating } & Value \\
\hline Very less & 20 \\
Less & 40 \\
Enough & 60 \\
Good & 80 \\
Very Good & 100 \\
\hline
\end{tabular}

e. The Criteria of Guarantee Condition

The Table 7 explains the conditions of collateral to be submitted by the borrower. Here the cooperative employees analyze the conditions of the collateral eligibility. The following must be checked against the conditions of guarantee:

1. Very less is a condition when the collateral condition a motorbike or a car is not feasible, the name of the ownership documents does not conform the credit borrower's name, and the rice fields / ponds, land, houses are state-owned land, or are still in dispute

2. Enough is a condition when the collateral condition of a motorbike or a car is reasonable, the name of the ownership documents does not conform the borrower's name, the house still has arrears / not paid off (semi-permanent), and the land owned by the borrower also has arrears.

3. Good is a condition when the collateral condition of a car or a motorcycle is feasible, but the documents do not belong to the borrower. The house is permanent but not in the name of the borrower and the land is privately owned and paid in full, but the certificate is not in the borrower's name.

4. Very Good is a condition when the credit guarantees condition of a motorbike or car is feasible and the documents belong to the credit borrower. The house is a private residence with the borrower's name in the certificate of title. The land certificate is in the name of the borrower and has been fully paid / no arrears.

Table 8. Input of Applicant Data

\begin{tabular}{cccccc}
\hline Name & $\begin{array}{c}\text { Deposit } \\
\text { Amount }\end{array}$ & Income & Character & Guarantee & $\begin{array}{c}\text { Conditions } \\
\text { of Guarantee }\end{array}$ \\
\hline Diana & $<8000000$ & 5000000 & Pretty good & soil & very less \\
Feri Jalias & $>8000000$ & 6000000 & Very good & house & very less \\
Herni & $=8000000$ & 2000000 & Very good & rice fields & very good \\
Ida Dahlia & $=8000000$ & 4000000 & good & $\begin{array}{c}\text { soil } \\
\text { very good }\end{array}$ & very good
\end{tabular}

After the borrower's table is input, then the next step is to convert the data into match table in Table 9 that has been specified previously. The following table matches the values based on the input: 
Table 9. Match Value Table

\begin{tabular}{|c|c|c|c|c|c|}
\hline \multicolumn{6}{|c|}{ Data Utility Value Criteria } \\
\hline Name & $\begin{array}{l}\text { Deposit } \\
\text { Amount }\end{array}$ & Income & Character & Guarantee & $\begin{array}{c}\text { Conditions of } \\
\text { Guarantee }\end{array}$ \\
\hline Diana & 30 & 20 & 60 & 80 & 20 \\
\hline Feri Jalias & 100 & 80 & 100 & 100 & 20 \\
\hline Herni & 70 & 40 & 100 & 40 & 100 \\
\hline Ida Dahlia & 70 & 60 & 80 & 80 & 100 \\
\hline Ihat Solihat & 100 & 80 & 100 & 20 & 100 \\
\hline
\end{tabular}

\section{Weight Correction}

Weight improvement is done by calculating the initial weight that has been determined at the cooperative (Table 3 .) where the initial weight is $\mathrm{W}=(5,3,3,4,3)$ and will be corrected to :

$$
\mathrm{Wj}=\frac{X j}{\sum w j}
$$

$$
\begin{array}{ll}
\mathrm{W} 1=\frac{100}{100+60+60+80+60}=0.278 & \mathrm{~W} 2=\frac{60}{100+60+60+80+60}=0.167 \\
\mathrm{~W} 3=\frac{60}{100+60+60+80+60}=0.167 & \mathrm{~W} 4=\frac{80}{100+60+60+80+60}=0.222 \\
\mathrm{~W} 5=\frac{60}{100+60+60+80+60}=0.167 &
\end{array}
$$

Table 10. Weight Correction

\begin{tabular}{lcc}
\hline Criteria Name & Weight & $\begin{array}{c}\text { Weight } \\
\text { Repair }\end{array}$ \\
\hline Deposit Amount & 100 & 0.278 \\
Income & 60 & 0.167 \\
Character & 60 & 0.167 \\
Guarantee & 80 & 0.222 \\
Conditions Of & 60 & 0.167 \\
Guarantee & & \\
\hline
\end{tabular}

Table 11. Data Si Vector Calculation

\begin{tabular}{lc}
\multicolumn{1}{c}{ Name } & Vector Vi Score \\
\hline Diana Azizah & 37 \\
Feri Jalias S & 74 \\
Herni Marlina & 63 \\
Ida Dahlia & 76 \\
Ihat Solihat & 67 \\
\hline
\end{tabular}

After getting the value of the improvement of the weights of each alternative above, then the next step is to do the Si Vector and Vi Vector calculations.

6. Vector Calculation of $\mathrm{Si}$

1. Diana Azizah

$$
S 1=\left(30^{0.278}\right)\left(20^{0.167}\right)\left(60^{0.167}\right)\left(80^{0.222}\right)\left(20^{0.167}\right)=37
$$

2. Herni Marlina

$$
S 2=\left(70^{0.278}\right)\left(40^{0.167}\right)\left(100^{0.167}\right)\left(40^{0.222}\right)\left(100^{0.167}\right)=63
$$

3. Feri Jalias $\mathrm{S}$

$$
S 3=\left(100^{0.278}\right)\left(80^{0.167}\right)\left(100^{0.167}\right)\left(100^{0.222}\right)\left(80^{0.167}\right)=74
$$

4. Ihat Solihat

$$
S 4=\left(100^{0.278}\right)\left(80^{0.167}\right)\left(100^{0.167}\right)\left(20^{0.222}\right)\left(100^{0.167}\right)=67
$$

5. Ida Dahlia

$$
S 5=\left(70^{0.278}\right)\left(60^{0.167}\right)\left(80^{0.167}\right)\left(80^{0.222}\right)\left(100^{0.167}\right)=76
$$


7. Vector Calculation of $\mathrm{S}$

$$
V i=\frac{\Pi_{j=1}^{n} x_{i j} w^{j}}{\Pi_{j=1}^{n}\left(X_{j}\right) w^{j}}
$$

1. Diana Azizah

$$
\begin{gathered}
V 6=\frac{37}{58+61+55+56+64+37+47+74} \\
+63+76+67+54+60+59+68+40 \\
41+40+58+64 \\
=0.032
\end{gathered}
$$

3. Feri Jalias $\mathrm{S}$

$$
\begin{gathered}
V 8=\frac{74}{58+61+55+56+64+37+47+74} \\
+63+76+67+54+60+59+68+40 \\
41+40+58+64 \\
=0.064
\end{gathered}
$$

\section{Herni Marlina}

$$
\begin{gathered}
V 9=\frac{63}{58+61+55+56+64+37+47+74} \\
+63+76+67+54+60+59+68+40 \\
41+40+58+64 \\
=0.056
\end{gathered}
$$

4. Ihat Solihat

$$
\begin{gathered}
V 11=\frac{67}{58+61+55+56+64+37+47+74} \\
+63+76+67+54+60+59+68+40 \\
41+40+58+64 \\
=0.059
\end{gathered}
$$

5. Ida Dahlia

$$
\begin{gathered}
V 10=\frac{76}{58+61+55+56+64+37+47+74}=0.067 \\
+63+76+67+54+60+59+68+40 \\
41+40+58+64
\end{gathered}
$$

Table 12. Data of Calculating Vi

\begin{tabular}{lc}
\hline Name & Vector Vi \\
\hline Diana Azizah & 0.032 \\
Feri Jalias S & 0.064 \\
Herni Marlina & 0.056 \\
Ida Dahlia & 0.067 \\
Ihat Solihat & 0,059 \\
\hline
\end{tabular}

From the results of the calculation in addition to determining the credit worthiness of the Simpeunan Pameungkeut Banda Cooperative using the Weighted Product method of a sample of 20 selected borrowers, with a value limit of 0.045 , show the results of 16 borrowers who are eligible for credit loans, and 4 members who are not eligible for credit loans. The results of these calculations are in accordance with predetermined

\subsection{SMART Method}

In the SMART method the steps taken in Determining Number of Criteria, Determining Criteria Weight, Determining the weighting of each criterion, Borrowing Data Input, and Normalizing Criteria Weight are the same as the Weighted Product method. So here the authors will immediately explain in the next step

1. Calculating utility value

$$
u_{i}\left(a_{i}\right)=100 \frac{\left(C_{\text {out } i}-C_{\min }\right)}{\left(C_{\max }-C_{\min }\right)}
$$

Information :

- $u_{i}\left(a_{i}\right)$ : The value of the 1 st criteria utility for the $i$ iteration

- $C_{\max }$ : Maximum criterion value

- $C_{\min }:$ Minimum criterion value

- $C_{\text {out }}:$ The i value criterion 
1. Diana Azizah

$$
\begin{aligned}
& \text { Deposit Amount }=100 \frac{(30-30)}{(100-30)} \\
& =100 \frac{0}{70}=0 \\
& \text { Income }=100 \frac{(20-20)}{(100-20)} \\
& \text { Character }=100 \frac{(60-20)}{(100-20)} \\
& =100 \frac{40}{80}=50 \\
& \text { Guarantee }=100 \frac{(80-20)}{(100-20)} \\
& \text { Conditions of Guarantee }=100 \frac{(20-20)}{(100-20)} \\
& =100 \frac{0}{80}=0
\end{aligned}
$$$$
=100 \frac{0}{80}=0
$$$$
=100 \frac{60}{80}=75
$$

2. Dian Muharam

$$
\begin{array}{cr}
\text { Deposit Amount =100 } \frac{(100-30)}{(100-30)} & \text { Income }=100 \frac{(60-20)}{(100-20)} \\
=100 \frac{70}{70}=100 & =100 \frac{40}{80}=50
\end{array}
$$

3. Ida Dahlia

$$
\begin{aligned}
& \text { Deposit Amount }=100 \frac{(70-30)}{(100-30)} \quad \text { Income }=100 \frac{(60-20)}{(100-20)} \\
& =100 \frac{40}{70}=57.1 \quad=100 \frac{40}{80}=50 \\
& \begin{aligned}
\text { Character }=100 & \frac{(80-20)}{(100-20)} \quad \text { Guarantee }=100 & \frac{(80-20)}{(100-20)} \\
& =100 \frac{60}{80}=75 & =100 \frac{60}{80}=75
\end{aligned} \\
& \text { Conditions of Guarantee }=100 \frac{(100-20)}{(100-20)} \\
& =100 \frac{80}{80}=100
\end{aligned}
$$


4. Ihat Solihat

$$
\begin{aligned}
& \text { Deposit Amount } \\
& =100 \frac{(100-30)}{(100-30)} \\
& =100 \frac{70}{70}=100 \\
& \text { Character }=100 \frac{(80-20)}{(100-20)} \\
& =100 \frac{60}{80}=75 \\
& \text { Income }=100 \frac{(80-20)}{(100-20)} \\
& =100 \frac{60}{80}=75 \\
& \text { Guarantee }=100 \frac{(80-20)}{(100-20)} \\
& =100 \frac{60}{80}=75 \\
& \text { Conditions of Guarantee }=100 \frac{(100-20)}{(100-20)} \\
& =100 \frac{80}{80}=100
\end{aligned}
$$

5. Feri Jalias $\mathrm{S}$

$$
\begin{array}{cc}
\text { Deposit Amount }=100 \frac{(100-30)}{(100-30)} & \text { Income }=100 \frac{(80-20)}{(100-20)} \\
=100 \frac{70}{70}=100 & =100 \frac{60}{80}=75
\end{array}
$$

2. Calculating Final Value by SMART method

$$
u\left(a_{i}\right)=\sum_{j=1}^{m} w_{j} u_{i}\left(a_{i}\right)
$$

1. Diana Azizah

$(0.278 \times 0)+(0.167 \times 0)+(0.167 \times 50)+(0.222 \times 75)+(0.167 \times 0) \quad=25$

2. Dian Muharam

$(0.278 \times 100)+(0.167 \times 50)+(0.167 \times 75)+(0.222 \times 75)+(0.167 \times 0)=65.3$

3. Ida Dahlia

$(0.278 \times 57.1)+(0.167 \times 50)+(0.167 \times 75)+(0.222 \times 75)+(0.167 \times 100)=70.0$

4. Ihat Solihat

$(0.278 \times 100)+(0.167 \times 75)+(0.167 \times 100)+(0.222 \times 0)+(0.167 \times 100)=73.6$

5. Feri Jalias

$(0.278 \times 100)+(0.167 \times 75)+(0.167 \times 100)+(0.222 \times 100)+(0.167 \times 0)=79.2$ 
From the results of the calculation in addition to determining the credit worthiness of the Simpeunan Pameungkeut Banda Cooperative using the SMART method of a sample of 20 selected borrowers, with a limit on the value of eligibility 45 gets the results of 16 borrowers who are eligible to get credit loans, and 4 members who are not eligible to get credit loans. These calculations are in accordance with predetermined criteria. From the results of the analysis, the authors conclude that the SMART method is more effective in determining eligibility

\section{Summary}

Based on the analysis that has been presented, the decision support system for creditworthiness selection can optimize the work of cooperative employees. The results of the Weighted Product calculation method to select prospective borrowers shows the highest value of 0.067 and the lowest value of 0.032 . Besides that, the SMART method has the highest value of 79.2 and the lowest value of 25 . To conclude, the SMART method is more effective in determining the provision of creditworthiness because the results of calculations with existing data are more valid.

\section{References}

[1] Gobai, A. (2019). Analisis Kinerja Keuangan Koperasi Unit Desa Langgeng Desa Inauga Kecamatan Mimika Baru Kabupaten Mimika. 8(1), 98-105.

[2] Fahmi Irham, Manajemen Perkreditan. Bandung, 2014.

[3] S. K. Muslimin B, "Sistem Pendukung Keputusan Dalam Penilaian Kinerja Dosen Menggunakan Metode Weighted Product ( Studi Kasus : Dosen Stmik Balikpapan )," vol. 1, no. Snrik, pp. 1-7, 2016.

[4] M. W. Product dan K. Koperasi, "Sistem pendukung keputusan kelayakan pemberian kredit pada koperasi simpan pinjam sekawan dengan menggunakan metode weighted product 1,2," pp. 1-11.

[5] Muslimin B, S. K. (2016). Sistem Pendukung Keputusan Dalam Penilaian Kinerja Dosen Menggunakan Metode Weighted Product ( Studi Kasus : Dosen Stmik Balikpapan ). 1(Snrik), 1-7.

[6] Oktaviana, R., \& Himawan, H. (2015). Pelanggan Terbaik Pada Tb . Bangun Jaya. Universitas Dian Nuswantoro, 1-9.

[7] A. B. Marendra, D. Nugroho, and I. A. Prabowo, "Klasifikasi Pemain Futsal Menggunakan Metode Simple Multi Attributte Rating Technique (SMART)," J. Teknol. Inf. dan Komun., vol. 6, no. 2, 2019.

[8] Marendra, A. B., Nugroho, D., \& Prabowo, I. A. (2019). Klasifikasi Pemain Futsal Menggunakan Metode Simple Multi Attributte Rating Technique (SMART). Jurnal Teknologi Informasi Dan Komunikasi (TIKomSiN), 6(2). https://doi.org/10.30646/tikomsin.v6i2.377

[9] Sistem Pendukung Keputusan Pendukung, S., Penilaian, K., \& Kredit, K. (2018). ... (Riyantomo dkk.). 62-68. 